\title{
Perlindungan Hukum Terhadap Kejahatan Cybersquatting Di Indonesia
}

\author{
Reva Amalia \\ Pascasarjana Magister Ilmu Hukum Universitas Islam Indonesia Yogyakarta \\ Indonesia \\ Jln. Cik Di Tiro No. 1 Yogyakarta, Indonesia 55223 \\ revaamalia87@gmail.com
}

\begin{abstract}
This study aims to determine the definition of cybersquatting and its legal protection in Indonesia. This is a normative research that uses conceptual and statutory approaches. The results of this study conclude that essentially the definition of cybersquatting has not been explicitly defined nor regulated in the laws and regulations in Indonesia. However, cybersquatting can be understood as the act of registering a domain name associated with someone else's company name and then trying to make a profit by selling it to that company. Legal protection against cybersquating is regulated in several laws and regulations, such as Article 23 and Article 38 of Law No. 11 of 2008 on Information and Electronic Transactions, as well as Article 83, Article 100, Article 101, Article 102 of Law No. 20 of 2016 concerning Brands and Geographical Indications. In addition, legal protection for brands' domain names in regards to cybersquatting can be seen from the government's attempt by delegating responsibility to Indonesian Domain Name Manager (PANDI)
\end{abstract}

Key Words: Cybersquatting; legal protection; offences

\begin{abstract}
Abstrak
Penelitian ini bertujuan untuk mengetahui definisi cybersquatting dan perlindungan hukumnya di Indonesia. Penelitian ini merupakan penelitian normatif yang menggunakan pendekatan konseptual dan perundang-undangan. Hasil penelitian ini menyimpulkan bahwa pada dasarnya definisi cybersquatting belum secara tegas dijelaskan atau diatur dalam peraturan perundang-undangan di Indonesia. Akan tetapi, cybersquatting dapat didefinisikan sebagai tindakan mendaftarkan domain yang terasosiasi dengan nama perusahaan orang lain dan kemudian berusaha mencari keuntungan dengan menjualnya kepada perusahaan tersebut. Perlindungan hukum terhadap kejahatan cybersquating diatur dalam beberapa peraturan perundang-undangan yaitu seperti Pasal 23 dan Pasal 38 Undang-Undang Nomor 11 tahun 2008 tentang Informasi dan Transaksi Elektronik, serta Pasal 83, Pasal 100, Pasal 101, Pasal 102 Undang-Undang Nomor 20 Tahun 2016 tentang Merek dan Indikasi Geografis. Selain itu, perlindungan hukum terhadap nama domain yang berhubungan dengan merek terkait tindakan cybersquatting terlihat dari upaya pemerintah melalui pemberian tanggung jawab kepada PANDI (Pengelola Nama Domain Indonesia).
\end{abstract}

Kata-kata Kunci: Perlindungan Hukum; kejahatan; cybersquatting 


\section{Pendahuluan}

Pengaruh globalisasi dengan penggunaan sarana teknologi informasi dan komunikasi telah mengubah pola hidup masyarakat, dan berkembang dalam tatanan kehidupan baru sehingga mendorong terjadinya perubahan sosial, ekonomi, budaya, pertahanan, keamanan, dan penegakan hukum. ${ }^{1}$ Metode komunikasi dan informasi berkembang begitu cepat sehingga memungkinkan setiap orang untuk bersosialisasi dengan orang lain dalam kurun waktu yang tidak terlalu lama. ${ }^{2}$

Kemunculan internet dapat dikatakan merupakan hasil dari revolusi informasi yang sangat mengagumkan, membanggakan oleh karena secara mendasar mengandung ciri praktis dan memudahkan, baik untuk penggunaan secara orang perorangan maupun organisasi atau institusional, dalam berbagai aspek kehidupan. Ciri tersebut tidak terlepas dari kekuatan dan kecepatan internet dalam tatanan operasionalnya yang antara lain dapat menembus ruang dan waktu. $^{3}$ Barda Nawawi menyatakan bahwa dunia nyata dan maya (cyberspace) tidak terpisah secara tegas yang artinya aktifitas di internet walaupun dianggap sebagai suatu aktifitas maya, dalam pengaturannya tidak dapat dilepaskan dari manusia dalam dunia nyata. Ini dikarenakan internet sebagai sebuah teknologi menuntut peran manusia dalam pengoperasiannya. Manusia dalam alam nyatalah yang bertanggung jawab atas akibat dari perbuatannya" ${ }^{4}$

Kemajuan internet saat ini, khususnya Teknologi Informasi di Indonesia, memiliki banyak dampak baik maupun dampak buruk dalam berbagai aspek kehidupan masyarakat, salah satunya berdampak pula pada kegiatan perdagangan, pemasaran produk barang maupun jasa menggunakan media internet untuk pemasarannya. Adanya pemasaran melalui internet, maka merek dari perusahaan tersebut dibentuk ke dalam suatu nama domain di internet. Penggunaan nama domain dapat disalahgunakan oleh pihak yang ingin mendapatkan keuntungan dari ketenaran suatu merek, sehingga muncul istilah pembajakan merek melalui sebuah nama domain.

Cybersquatting merupakan tindakan pembajakan merek melalui nama domain tersebut, pihak yang membajak atau membuat nama domain dengan meniru nama merek terkenal lalu menjualnya kembali kepada pihak lain. Bagi perusahaan yang sudah memiliki reputasi yang bagus dan dikenal dimasyarakat luas, hal ini tentulah sangat meresahkan, karena hal ini berkaitan dengan nama

\footnotetext{
${ }^{1}$ Siswanto Sunarso, Hukum Informasi dan Transaksi Elektronik, Rineka Cipta, Jakarta, 2009, hlm. 1.

${ }^{2}$ Hariman Satria, Anatomi Hukum Pidana Khusus, UII Press, Yogyakarta, 2014, hlm. 137.

3 Tim penelitian dibawah pimpinan Suharyo, Penerapan Bantuan Timbal Balik dalam Masalab Pidana Terhadap Kasus-Kasus Cybr Crime, Badan Pembinaan Hukum Nasional, Jakarta, 2002, hlm. 2.

${ }^{4}$ Barda Nawawi Arief, Tindak Pidana Mayantara, Raja Grafindo, Jakarta, 2006, hlm. 11.
} 
besar dan nama baik perusahaan. Selain itu, kejahatan cybersquatting juga umumnya dilakukan untuk menyalahgunakan nama orang-orang berpengaruh atau bisa disebut terkenal, dengan tujuan berbeda-beda yang jelas ini dapat merugikan orang tersebut. Jadi, hal ini jelas akan sangat berbahaya bagi perusahaan ataupun orang lain sehingga perlu dilakukan kajian lebih komprehensif mengenai tindak pidana cybersquatting.

\section{Rumusan Masalah}

Berdasarkan latar belakang masalah di atas, rumusan masalah penelitian ini adalah pertama, apa yang dimaksud dengan cybersquatting? Kedua, bagaimanakah perlindungan hukum cybersquatting menurut hukum di Indonesia?

\section{Tujuan Penelitian}

Tujuan yang ingin dicapai dari penelitian ini adalah pertama, untuk mengetahui apa yang dimaksud dengan cybersquatting. Kedua, untuk mengetahui perlindungan hukum cybersquatting menurut hukum di Indonesia.

\section{Metode Penelitian}

Penelitian ini termasuk ke dalam penelitian hukum normatif yang menggunakan pendekatan konseptual dan perundang-undangan. Objek penelitian ini difokuskan untuk mengkaji mengenai cybersquatting dan perlindungan hukumnya menurut hukum di Indonesia. Data yang diperoleh dari hasil penelitian dianalisis menggunakan teknik deskriptif, yaitu memberikan gambaran atau pemaparan atas subjek dan objek penelitian sebagaimana hasil penelitian yang dilakukannya.

\section{Hasil Penelitian dan Pembahasan}

\section{Pengertian Cybersquatting}

Cybersquatting adalah tindakan mendaftarkan domain yang terasosiasi dengan nama perusahaan orang lain dan kemudian berusaha mencari keuntungan dengan menjualnya kepada perusahaan tersebut. ${ }^{5}$ Tujuan pelaku mendahului mendaftarkan domain name tersebut adalah untuk ditawarkan kepada pihak yang sesungguhnya akan menggunakan domain name tersebut dengan memperoleh keuntungan besar. Pelaku cybersquatting disebut cybersquatter. Meskipun demikian, pada dasarnya defenisi mengenai cybersquatting sendiri

5 Abi Jam'an Kurnia, "Perlindungan Hukum di Indonesia atas Tindakan Cybersquatting", https://m.hukumonline.com/klinik/detail/ulasan/cl6560/perlindungan-hukum-di-indonesia-atas-tindakanicybersquatting-i/ , diakses pada 7 September 2020 pukul 23.17 wib. 
secara tegas belum dijelaskan atau diatur dalam peraturan perundang-undangan di Indonesia.

Pengertian cybersquatting umumnya mengacu pada praktek membeli nama domain yang menggunakan nama- nama bisnis yang sudah ada atau nama orangorang terkenal dengan maksud untuk menjual nama untuk keuntungan bagi bisnis mereka. Karena suatu domain name adalah aset yang sangat berharga karena dapat diperjual belikan, disewa, dapat menjadi situs pemasang iklan sehingga menjadi sumber keuangan, bahkan dapat dijaminkan, maka para penjahat melihat peluang untuk menjadikan domain name sebagai objek perdagangan, yaitu dengan melakukan cybersquatting. Terkait hal ini, Budi Raharjo menyatakan, bahwa kejahatan nama domain yang pada intinya dapat terjadi dalam tiga bentuk yang salah satunya adalah cybersquatting ini yaitu, kegiatan mendaftarkan nama domain badan usaha, organisasi, orang lain atau pihak lain di luar dirinya kemudian dijual pada pemilik nama domain tersebut dengan harga yang jauh lebih mahal (cybersquatter). Jenis ini mirip calo karcis yang tujuan utama mencari keuntungan pribadi dengan merugikan orang lain. ${ }^{6}$

Pemaparan di atas menunjukkan bahwa tingkah laku jahat terjadi dalam sebuah situasi tertentu sesuai dengan apa yang dikehendaki, dan apa yang didefinisikan oleh seseorang sesuai dengan pemahamannya. Secara lengkap Sutherland mengajukan 9 proposisi tentang proses terjadinya tingkah laku jahat, sebagaimana dikemukakan Bartollas, yaitu pertama, tingkah laku jahat, sebagaimana perilaku lainnya, dipelajari dari orang lain. Perilaku jahat bukan perilaku yang diwariskan. Kedua, tingkah laku jahat dipelajari dalam hubungan interaksi dengan orang lain melalui proses komunikasi, baik langsung maupun tidak langsung. Ketiga, bagian terpenting dari mempelajari tingkah laku jahat terjadi dalam kelompok intim, lebih efektif dibandingkan dengan komunikasi bentuk lainnya, misalnya lewat film atau surat kabar.

Keempat, mempelajari tingkah laku jahat termasuk di dalamnya teknik melakukan kejahatan dan motivasi / dorongan atau alasan pembenar termasuk sikap-sikap. Kelima, arah dari motif dan dorongan tertentu dipelajari melalui definisi-definisi dari peraturan perundang- undangan. Dalam masyarakat kadang- kadang anak berhubungan dengan orang-orang yang melihat apa yang diatur dalam peraturan perundang-undangan/hukum sebagai sesuatu yang perlu diperhatikan dan dipatuhi, tetapi kadang seorang anak juga dapat berhubungan dengan orang- orang yang melihat aturan hukum sebagai sesuatu yang memberi peluang untuk melakukan kejahatan). Keenam, seseorang menjadi

${ }^{6}$ Budi Raharjo, memahami teknologi informasi; menyikapi dan membekali diri terhadap peluang dan tantangan teknologi informasi, elekmedia Komputindo, Jakarta, 2002, hlm. 116-118 
delinkuen, karena ekses dari pola-pola pikir yang lebih melihat aturan hukum sebagai pemberi peluang dilakukannya kejahatan daripada yang melihat hukum sebagai sesuatu yang harus diperhatikan dan dipatuhi.

Ketujuh, asosiasi diferensial ini bervariasi tergantung dari frekuensi, jangka waktu, prioritas dan intensitasnya. Jadi dampak negatif yang ditimbulkan oleh kelompok (peers groups) tergantung pada frekuensi, seberapa lama, pengalaman, dan intensitas dalam bergaul. Kedelapan, proses mempelajari tingkah laku jahat melalui pergaulan dengan pola kejahatan dan antikejahatan melibatkan semua mekanisme yang berlaku dalam setiap proses belajar. Jadi mempelajari tingkah laku jahat tidak terbatas pada upaya meniru tingkah laku. Kesembilan, sekalipun tingkah laku jahat merupakan pencerminan dari kebutuhan-kebutuhan umum dan nilai-nilai, tetapi tingkah laku jahat tersebut tidak dapat dijelaskan melalui kebutuhan umum dan nilai-nilai, karena tingkah laku yang tidak jahat pun merupakan pencerminan dari kebutuhan-kebutuhan umum dan nilai-nilai yang sama. Jadi motif seseorang yang terlibat kenakalan berbeda dengan perilaku pada umumnya, karena dasar pemahamannya juga berbeda. ${ }^{7}$

Pasal 1 angka 20 Undang-Undang Nomor 19 Tahun 2016 tentang Perubahan atas Undang-Undang Nomor 11 Tahun 2008 tentang Informasi dan Transaksi Elektronik mengatur bahwa definisi nama domain adalah alamat internet penyelenggara negara, orang, badan usaha, dan/atau masyarakat, yang dapat digunakan dalam berkomunikasi melalui internet, yang berupa kode atau susunan karakter yang bersifat unik untuk menunjukkan lokasi tertentu dalam internet. Merek sebagai salah satu bentuk HKI memegang peranan penting dalam era perdagangan global, terutama dalam menjaga persaingan usaha yang sehat. Untuk maksud tersebut mutlak diperlukan adanya suatu peraturan perundangundangan dibidang ini yang memadai dan dapat diandalkan. Hal ini karena pada praktiknya banyak sekali merek-merek yang sesungguhnya dilindungi oleh hukum merek (dalam dunia nyata) ternyata telah banyak digunakan dalam bentuk nama domain (domain name) oleh pihak lain yang bukan pemilik hak atas merek tersebut. 8

Pasal 1 angka (1) Undang-Undang Nomor 20 Tahun 2016 tentang Merek dan Indikasi Geografis juga menjelaskan bahwa merek adalah tanda yang dapat ditampilkan secara grafis berupa gambar, logo, nama, kata, huruf, angka, susunan, warna, dalam bentuk 2 dimensi dan/atau 3 dimensi, suara, hologram,

7 Hardianto Djanggih, Nurul Qamar, "Penerapan Teori-Teori Kriminologi dalam Penanggulangan Kejahatan Siber (Cyber Crime)", Jurnal Pandecta Volume 13. Number 1. June 2018, Universitas Negeri Semarang, hlm. 16

${ }^{8}$ Muhammad amirulloh, "Cybersquatting dan Typosquatting Sebagai Suatu Bentuk Pelanggaran Merek Dalam Kajian Filsafat Ilmu”, makalah, Fakultas Hukum, Universitas Padjadjaran, 2009, hlm. 2. 
atau kombinasi dari 2 atau lebih unsur tersebut untuk membedakan barang dan/atau jasa yang diproduksi oleh orang atau badan hukum dalam kegiatan perdagangan barang dan/atau jasa.

\section{Perlindungan Hukum Cybersquatting di Indonesia}

Hak atas merek ialah hak eksklusif yang diberikan oleh negara kepada pemilik merek yang terdaftar, jika tidak terdaftar maka tidak memperoleh perlindungan hukum. Hak atas merek diberikan untuk jangka waktu 10 tahun dan dapat diperpanjang tiap 10 tahun. Sistem perlindungan merek di Indonesia menganut sistem konstitutif yakni hak atas merek yang timbul karena pendaftaran, dan hak atas merek diberikan kepada pendaftar pertama. Selain itu, perlindungan hukum diberikan terhadap merek yang terdaftar pada kelas masing-masing disesuaikan dengan barang dan/atau jasa. ${ }^{9}$

Perlindungan terhadap hak atas merek yang dilindungi hanyalah merek yang telah terdaftar dan merupakan pengakuan atas pembenaran akan hak atas merek seseorang, dapat dibuktikan dengan adanya sertifikat pendaftaran merek sehingga dapat memperoleh perlindungan hukum. Pendaftaran merek berdasarkan sistem konstitutif (first ti file system) yang berarti hak atas merek hanya dapat diberikan kepada pendaftar yang terlebih dahulu mendaftarkannya. Secara hukum sebenarnya tindakan cybersquatting belum diatur secara tegas dalam peraturan perundang-undangan di Indonesia, tetapi pelanggaran terhadap cybersquatting tersebut sudah pernah terjadi di Indonesia seperti kasus Sony Corp vs Sony AK dan kasus Mustika Ratu.

Nama domain tersebut telah diatur di dalam Pasal 23 Undang-Undang Nomor 11 Tahun 2008 tentang Informasi dan Transaksi Elektronik yang menyatakan bahwa setiap penyelenggara negara, orang, badan usaha, dan/atau masyarakat berhak memiliki nama domain berdasarkan prinsip pendaftar pertama. Pasal tersebut juga menyatakan bahwa pemilikan dan penggunaan nama domain tersebut harus didasarkan pada iktikad baik, tidak melanggar prinsip persaingan usaha secara sehat, dan tidak melanggar hak orang lain. Selain itu, setiap penyelenggara negara, orang, badan usaha, atau masyarakat yang dirugikan karena penggunaan nama domain secara tanpa hak oleh orang lain, berhak mengajukan gugatan pembatalan nama domain dimaksud.

Pada prakteknya, merek dagang cenderung menjadi nama domain perusahaan yang sama. Hal ini memberi gambaran umum pada masyarakat bahwa nama domain yang terdafatar adalah merek dagang yang ada di dunia

9 Setia Dharma, "Perlindungan Merek Terdaftar Dari Kejahatan Dunia Maya Melalui Pembatasan Pendaftaran Nama Domain", Jurna Cita Hukum, Fakultas Syariah dan Hukum UIN Syarif Hidayatullah Jakarta,Vol. II No. 2 Desember 2014, hlm. 197 
nyata, sehingga tumbuh dalam pandangan publik nama situs menggambarkan merek dagang. Tidak dapat dipungkiri bahwa pendaftaran nama domain orang lain atau merek dagang terkenal oleh mereka yang tidak memiliki hak atas nama tersebut menimbulkan masalah pada praktek dan keberadaannya. ${ }^{10}$

Untuk memperoleh nama suatu domain, para pihak yang bersangkutan untuk meminta nama domain tersebut telah dinyatakan secara pribadi bertanggung jawab dan menjamin bahwa pengajuan permintaan pendaftaran nama domain yang dilakukannya yaitu telah didasari dengan suatu itikad yang baik dan tidak merugikan bagi kepentingan atas keberadaan nama suatu domain yang dimintakan tersebut, maka dari itu telah diberlakukan asas First Come First served. ${ }^{11}$ Setiap kepemilikan dan penggunaan dari suatu nama domain harus didasari dengan itikad baik dan tidak melanggar dari prinsip persaingan usaha yang tidak sehat dan tidak melanggar hak milik orang lain.

Kerugian dari perbuatan melanggar hukum tersebut dapat berupa kerugian harta kekayaan atau meteriil dan imateriil, maka hal tersebut dapat dilakukan gugatan sebagaimana yang telah tercantum dalam Pasal 38 UU ITE yang mengatur bahwa setiap orang dapat mengajukan gugatan terhadap pihak yang menyelenggarakan sistem elektronik dan/atau menggunakan teknologi informasi yang menimbulkan kerugian. Pasal tersebut juga mengatur bahwa masyarakat dapat mengajukan gugatan secara perwakilan terhadap pihak yang menyelenggarakan sistem elektronik dan/atau menggunakan teknologi informasi yang berakibat merugikan masyarakat, sesuai dengan ketentuan peraturan perundang- undangan.

Selain UU ITE, cybersquatting juga diatur dalam Pasal 83 Undang-Undang Nomor 20 Tahun 2016 tentang Merek dan Indikasi Geografis menyebutkan bahwa pemilik merek terdaftar dan/atau penerima lisensi merek terdaftar dapat mengajukan gugatan terhadap pihak lain yang secara tanpa hak menggunakan merek yang mempunyai persamaan pada pokoknya atau keseluruhannya untuk barang atau jasa yang sejenis berupa gugatan ganti rugi, dan/atau penghentian semua perbuatan yang berkaitan dengan penggunaan merek tersebut. Gugatan tersebut diajukan kepada pengadilan niaga dan dapat diajukan oleh pemilik merek terkenal berdasarkan putusan pengadilan.

10 Abdul Wahid, dan Mohammad Labib, Kejahatan Mayantara (Cyber Crime), Cet.1, Refika Aditama, Bandung, 2005, hlm. 32

11 Saghara Luthfillah Fazari, "Perlindungan Nama Domain Merek Terkenal Terhadap Tindakan Cybersquatting di Internet Menurut Hukum Positif Indonesia”, Skripsi, Fkaultas Hukum, Universitas Brawijaya, 2014, hlm. 11. 
Ketentuan pidana sebagai bentuk perlindungan hukum terhadap tindak pidana cybersquatting juga dijelaskan dalam beberapa pasal Undang-Undang Merek dan Indikasi Geografis. Salah satunya yaitu Pasal 100 yang mengatur 3 ketentuan pidana berikut, pertama, setiap orang yang dengan tanpa hak menggunakan merek yang sama pada keseluruhannya dengan merek terdaftar milik pihak lain untuk barang dan/atau jasa sejenis yang diproduksi dan/atau diperdagangkan, dipidana dengan pidana penjara paling lama 5 tahun dan/atau denda paling banyak Rp. 2.000.000.000,00.

Kedua, setiap orang yang dengan tanpa hak menggunakan merek yang mempunyai persamaan pada pokoknya dengan merek terdaftar milik pihak lain untuk barang dan/atau jasa sejenis yang diproduksi dan/atau diperdagangkan, dipidana dengan pidana penjara paling lama 4 tahun dan/atau denda paling banyak Rp. 2.000.000.000,00. Ketiga, setiap orang yang melanggar ketentuan pidana tersebut yang jenis barangnya mengakibatkan gangguan kesehatan, gangguan lingkungan hidup, dan/atau kematian manusia, dipidana dengan pidana penjara paling lama 10 tahun dan/atau denda paling banyak Rp. 5.000.000.000,00.

Ketentuan pidana tersebut juga diatur dalam Pasal 101, yaitu pertama, setiap orang yang dengan tanpa hak menggunakan tanda yang mempunyai persamaan pada keseluruhan dengan indikasi geografis milik pihak lain untuk barang dan/atau produk yang sama atau sejenis dengan barang dan/atau produk yang terdaftar, dipidana dengan pidana penjara paling lama 4 tahun dan/atau denda paling banyak Rp. 2.000.000.000,00. Kedua, setiap orang dengan tanpa hak menggunakan tanda yang mempunyai persamaan pada pokoknya dengan indikasi geografis milik pihak lain untuk barang dan/atau produk yang sama atau sejenis dengan barang dan/atau produk yang terdaftar, dipidana dengan pidana penjara paling lama 4 tahun dan/atau denda paling banyak Rp. 2000.000.000,00. Selain itu, Pasal 102 juga mengatur bahwa setiap orang yang memperdagangkan barang dan/atau jasa dan/atau produk yang diketahui atau patut diduga mengetahui bahwa barang dan/atau jasa dan/atau produk tersebut merupakan hasil tindak pidana sebagaimana disebutkan di atas dipidana dengan pidana kurungan paling lama 1 tahun atau denda paling banyak Rp. 200.000.000,00.

Adakalanya nama domain dapat menjadi merek dagang, apabila pemilik merek dagang kemudian mendaftarkan ke kantor pengelola nama domain, sehingga nama merek dagangnya tidak bisa didaftarkan lagi oleh orang lain.12 Oleh karena itu, perlindungan hukum terhadap nama domain yang berhubungan

${ }^{12}$ Sabartua Tampubolon, Aspek Hukum Nama Domain di Internet, Tatanusa, Jakarta, 2003, hlm. 39 
dengan merek terkait tindakan cybersquatting itu juga terdapat sarana dari upaya pemerintah melindungi nama domain ini, yaitu melalui pemberian tanggung jawab kepada PANDI (Pengelola Nama Domain Indonesia). PANDI di sini bertugas sebagai pembuat dan perancang aturan-aturan terhadap nama domain yang sesuai dengan ketentuan yang telah ditetapkan berdasarkan Pasal 23 Undang-Undang ITE. Adapun kewenangan yang dimiliki oleh PANDI yakni berwenang untuk mengelola nama domain dalam media internet, menyampaikan informasi persyaratan-persyaratan untuk membuat suatu nama domain. Adapun salah satu syarat pembuatan nama domain yaitu dalam penamaan suatu nama domain harus sesuai dengan ketentuan yang telah berlaku. ${ }^{13}$

Langkah pencegahan pelanggaran mengenai nama domain yang dilakukan PANDI yaitu dengan menetapkan kebijakan nama domain yang sesuai UndangUndang Informasi dan Transaksi Elektronik (ITE), Rancangan Peraturan Pemerintah tentang Penyelenggara Informasi dan Transaksi Elektronik (RPP-PITE), dan juga peraturan menteri komunikasi dan Informasi Nomor 28/PER/M.KOMINFO/9/2006 yang mengelola nama domain khusus untuk situs web resmi pemerintah, baik pemerintah pusat maupun pemerintah daerah. Proses pencegahan pelanggaran terkait nama domain yang dilakukan oleh PANDI juga telah menggunakan software tertentu, yang dilakukan dengan menggunakan sistem registrasi yang berlaku atau yang sedang berjalan. Proses registrasi inilah PANDI dapat melakukan pencegahan terkait pelanggaran menggunakan nama domain yang mempunyai kesamaan dengan nama domain pihak lain sehingga dalam upayanya PANDI dalam hal pemberantasan terkait pelanggaran nama domain dalam media elektronik yang telah sering dilakukan yaitu menolak pendaftaran nama domain yang ternyata terbukti dan tidak sesuai dengan kebijakan nama domain (.id) yang telah tertanam pada sistem pendaftaran yang berlaku. ${ }^{14}$

Data PANDI menunjukkan bahwa jumlah pengguna domain .id dilaporkan mengalami peningkatan signifikan sebesar 45\% di 2019, sehingga kini sudah mencapai 135.812 nama. PANDI mencatat bahwa, per April 2019, pengguna domain .id mencapai 111.059 nama. Jumlah ini menyalip jumlah pengguna domain co id yang tercatat 110.111. Padahal, domain co.id sudah hadir lebih dulu, bahkan sebelum PANDI berdiri, pada 2007 sementara domain .id baru lahir pada 2014. Ketua PANDI mengatakan bahwa pertumbuhan pemakaian nama domain .id antara lain didorong oleh kemudahan syarat pendaftarannya yang

${ }_{13}$ Ni Komang Lugra Mega Triayuni Dewi dan Nyoman A. Martana, "Perlindungan hukum terhadap Pendaftaran Merek Nama Domain dalam Tindakan Cybersquatting di Indonesia”, Skripsi, Program Kekhususan Hukum Bisnis Fakultas Hukum, Universitas Udayana, hlm. 11.

14 PANDI (Pengelola Nama Domain Indonesia), kebjakan Pendaftaran nama domain, https://www.pandi.or.id/sites/default/files/u1/2.pdf 
kini tak lagi memerlukan unggahan dokumen. Selain itu, Yudho mengatakan bahwa domain .id juga populer karena cocok untuk pengguna di Indonesia dan di luar negeri untuk kebutuhan personal, perusahaan, organisasi, dan lain-lain.

Pada 2019, jumlah nama domain yang sudah terdaftar adalah 352.90. naik dari tahun ke tahun sejak 2015 sampai 2019. Berikut grafik perkembangan nama domain yang terdaftar. ${ }^{15}$

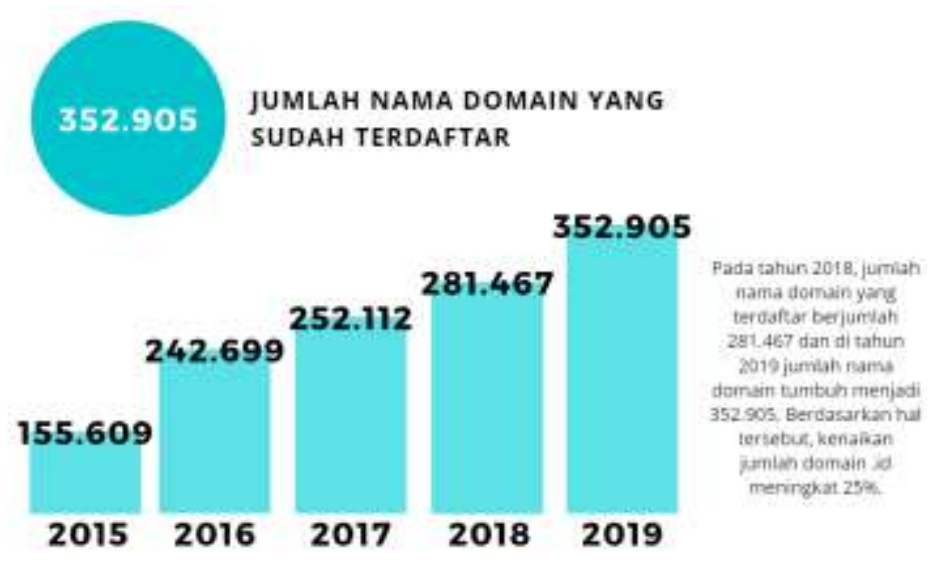

Gambar grafik peningkatan jumlah nama domain yang terdaftar

Beberapa pasal dari peraturan perundang-undangan yang ada di Indonesia, sebagaimana dipaparkan di atas, menunjukkan bahwa perlindungan hukum terhadap cybersquatting sudah mulai mengacu dan diatur, meskipun belum secara tegas dalam peraturan perundang-undangan mengenai pengertian cybesquatting sendiri. Oleh sebab itu, hal ini harusnya dapat dijadikan acuan atau landasan dari beberapa kasus mengenai cybersquatting. Cybersquatting yang dibiarkan atau tidak terindetifikasi oleh pemilik dagang yang memanfaakan website akan mengalami kerugian karena cenderung dapat menjadi sumber ancaman keamanan. Hal tersebut dikarenakan konsumen dimungkinkan tidak sampai pada sumber informasi yang benar yaitu pemilik domain yang benar, melainkan seringkali menuju sumber yang menyerupai domain yang bukan sebenarnya. Keutungan ini diambil dari kemungkinan pengguna internet melakukan kesalahan dalam melakukan interaksi internet seperti kesalahan menulis nama domain atau ketidaktahuaan alamat domain yang benar. ${ }^{16}$

\section{Penutup}

Pemaparan hasil penelitian di atas menunjukkan bahwa pada dasarnya definisi cybersquatting belum secara tegas dijelaskan atau diatur dalam peraturan

\footnotetext{
15 Pengelola Nama Domain Internet Indonesia, Laporan Tahunan 2019, Jakarta, 2020, hlm. 4.

16 Alusyanti Primawati, "Etika It Di Indonesia Studi Kasus: Cybersquatting Pada Domain PT. Mustika Ratu”, Jurnal SIMETRIS, Vol 7 No 1 April 2016 ISSN: 2252-4983, Universitas Indraprasta PGRI, hlm. 423
} 
perundang- undangan di Indonesia. Akan tetapi, cybersquatting dapat didefinisikan sebagai tindakan mendaftarkan domain yang terasosiasi dengan nama perusahaan orang lain dan kemudian berusaha mencari keuntungan dengan menjualnya kepada perusahaan tersebut. Perlindungan hukum terhadap kejahatan cybersquating diatur dalam beberapa peraturan perundang-undangan yaitu seperti Pasal 23 dan Pasal 38 Undang-Undang Nomor 11 Tahun 2008 tentang Informasi dan Transaksi Elektronik, serta Pasal 83, Pasal 100, Pasal 101, Pasal 102 Undang-Undang Nomor 20 Tahun 2016 tentang Merek dan Indikasi Geografis. Selain itu, perlindungan hukum terhadap nama domain yang berhubungan dengan merek terkait tindakan cybersquatting terlihat dari upaya pemerintah melalui pemberian tanggung jawab kepada PANDI (Pengelola Nama Domain Indonesia), yang bertugas sebagai pembuat dan perancang aturan-aturan terhadap nama domain yang sesuai dengan ketentuan yang telah ditetapkan berdasarkan Pasal 23 Undang-Undang ITE dan diatur dalam Undang-Undang Nomor 20 Tahun 2016 tentang Merek dan Indikasi Geografis.

\section{Daftar Pustaka}

\section{Buku}

Nawawi Arief, Barda, Tindak Pidana Mayantara, Raja Grafindo, Jakarta, 2006.

Pengelola Nama Domain Internet Indonesia, Laporan Tahunan 2019, Jakarta, 2020.

Raharjo, Budi, Memahami Teknologi Informasi; Menyikapi dan Membekali Diri Terhadap Peluang dan Tantangan Teknologi Informasi, elekmedia Komputindo, Jakarta, 2002.

Satria, Hariman, Anatomi Hukum Pidana Khusus, UII Press, Yogyakarta, 2014.

Sunarso, Siswanto, Hukum Informasi dan Transaksi Elektronik, Rineka Cipta, Jakarta, 2009.

Tampubolon, Sabartua, Aspek Hukum Nama Domain di Internet, Tatanusa, Jakarta 2003.

Tim penelitian di bawah pimpinan Suharyo, Penerapan Bantuan Timbal Balik dalam Masalah Pidana Terhadap Kasus-Kasus Cybr Crime, Badan Pembinaan Hukum Nasional, Jakarta, 2002.

Wahid, Abdul, dan Mohammad Labib, Kejahatan Mayantara (Cyber Crime), Refika Aditama, Bandung, 2005.

\section{Jurnal, Skripsi, Makalah}

Alusyanti Primawati, “Etika It Di Indonesia Studi Kasus: Cybersquatting Pada Domain Pt. Mustika Ratu", Jurnal SIMETRIS, Vol 7 No 1 April 2016 ISSN: 2252-4983, Universitas Indraprasta PGRI 
Hardianto Djanggih, dan Nurul Qamar, "Penerapan Teori-Teori Kriminologi dalam Penanggulangan Kejahatan Siber (Cyber Crime)", Jurnal Pandecta, Universitas Negeri Semarang Volume 13. Number 1. June 2018,

Komang Lugra Mega Triayuni Dewi, Ni dan Nyoman A. Martana, "Perlindungan hukum terhadap Pendaftaran Merek Nama Domain dalam Tindakan Cybersquatting di Indonesia", Skripsi, Program Kekhususan Hukum Bisnis Fakultas Hukum, Universitas Udayana

Muhammad Amirulloh, "Cybersquatting dan Typosquatting Sebagai Suatu Bentuk Pelanggaran Merek Dalam Kajian Filsafat Ilmu", makalah, Fakultas Hukum, Universitas Padjadjaran, 2009

Saghara Luthfillah Fazari, "Perlindungan Nama Domain Merek Terkenal Terhadap Tindakan Cybersquatting di Internet Menurut Hukum Positif Indonesia", Skripsi, Fakultas Hukum, Universitas Brawijaya, 2014.

Setia Dharma, "Perlindungan Merek Terdaftar Dari Kejahatan Dunia Maya Melalui Pembatasan Pendaftaran Nama Domain", Jurna Cita Hukum, Fakultas Syariah dan Hukum UIN Syarif Hidayatullah Jakarta Vol. II No. 2 Desember 2014.

\section{Internet}

Abi Jam'an Kurnia, "Perlindungan Hukum di Indonesia atas Tindakan Cybersquatting", https://m.hukumonline.com/klinik/detail/ulasan/ cl6560/perlindungan-hukum-di-indonesia-atas-tindakan- icybersquatting-i/

PANDI (Pengelola Nama Domain Indonesia), kebjakan Pendaftaran nama domain, https://www.pandi.or.id/sites/ default/files/u1/2.pdf 